\title{
Integrating the environmental and social sustainability pillars into the lean and agile supply chain management paradigms: A literature review and future research directions
}

\author{
Federica Ciccullo ${ }^{\text {a, }}$, Margherita Pero ${ }^{\text {a }}$, Maria Caridi ${ }^{\text {a }}$, Jonathan Gosling ${ }^{\text {b }}$, Laura Purvis ${ }^{\text {b }}$ \\ a Department of Management, Economics and Industrial Engineering, Politecnico di Milano, Via Lambruschini 4/b, 20156, Milan, Italy \\ b Cardiff Business School, Cardiff University, Cardiff, Aberconway Building, Colum Dr, Cardiff, CF10 3EU, UK
}

\begin{abstract}
Established supply chain management paradigms such as leanness, agility, and sustainability have received increased attention in the literature, but mainly as separate topics. However, while the importance of sustainability as a competitive priority has grown significantly in recent years, companies still try to reconcile the pressures of enhancing their supply chain efficiency and effectiveness. Thus, understanding what is the best way for companies to design and implement a system of practices that meets, on the one hand, the environmental and social requirements of a wide set of stakeholders and, on the other hand, the need to be lean (efficient and waste free) and/or agile (fast and flexible to the needs of the market place) is critical. Our paper develops a systematic literature review addressing the integration of lean, agile and sustainable supply chain management paradigms. 73 papers are analysed, deriving 6 types of integration between lean \& sustainable and agile \& sustainable supply chain paradigms. To achieve each type of integration, a set of practices are highlighted. Interestingly, the same practices can support different integration types. The paper discusses possible reasons behind these differences and provides future research directions. We suggest further studies should be devoted to investigating the agile - sustainable paradigms integration more in depth as well as the effect of including social dimension when considering the integration between established and sustainable supply chain paradigms. Moreover, we address the lack of empirical studies and the need to take an evolutionary perspective when looking at the integration. Finally, we suggest developing conceptual and empirical studies on whether and how integration between paradigms is contingent upon the strategic relevance of sustainability.
\end{abstract}

\footnotetext{
* Corresponding author.

E-mail address: federica.ciccullo@polimi.it (F. Ciccullo).
} 


\section{Introduction}

The current adverse global economic conditions have highlighted the need for organisations to integrate various supply chain paradigms, in order to meet customer demand efficiently and effectively, while adhering to the environmental and social requirements of a wider set of stakeholders. Supply chain paradigms are defined as set of practices coherent with a philosophical and cultural belief (Christopher and Towill, 2002; Narasimhan et al., 2006).

Rana Plaza collapse on April 24, 2013 (BBC, 2013), where more than 1000 workers were killed, as well as the Palm Oil scandal, which brought to light systematic social and environmental abuses in supply chain of major firms (Greenpeace, 2007; Amnesty International, 2016), are examples of the negative consequences of supply chain governance still too focused on the traditional goal of profit, disregarding or underestimating the social and environmental impact of the business.

A sustainable strategy should guide today's business. Coherently with the Triple Bottom Line (TBL) perspective of sustainability (Elkington, 1997), companies' strategy should simultaneously consider and balance economic, environmental and social goals (Carter and Rogers, 2008).

Focusing on the economic pillar, supply chain management practices should be adapted to the specific conditions of the business environment, in order to have profitable supply chains (Heydari, 2011). The Lean paradigm in supply chain management is applicable in stable, predictable and controllable business environments, whereas agile paradigm is required for a business to survive in an environment with unpredictable market changes. Naylor et al. (1999) define them as follows: "Leanness means developing a value stream to eliminate all waste, including time, and to ensure a level schedule. Agility means using market knowledge and a virtual corporation to exploit profitable opportunities in a volatile market place". The two concepts have more recently been extended to the supply chain, highlighting a need for companies to enlarge their focus to include intra-organisational aspects. According to Vonderembse et al. (2006) a lean supply chain "employs continuous improvement efforts that focus on eliminating waste or non-value steps along the chain".

Lee (2002) states that agile supply chains are aimed at "being responsive and flexible to the customers while the risk of supply shortage or related to upstream disruptions is hedged thanks to resource and inventory pooling and/or redundancy".

As far as the environmental pillar is concerned, recent literature suggests a new supply chain paradigm, the green supply chain paradigm (e.g. Dües et al., 2013; Carvalho and Cruz-Machado, 2011; Azevedo et al., 2012)., i.e. a set of practices aimed at reducing the environmental impact of the supply chain. Expanding this definition to the social pillar, the "sustainable supply chain paradigm" is defined as a set of supply chain practices aiming at reducing the environmental impact (measured in terms of e.g. carbon dioxide $\left(\mathrm{CO}_{2}\right)$ emissions, waste reduction) as well as at improving the social condition of different stakeholders, while contributing to the long term economic development of the supply chain (e.g. Pagell and Wu, 2009; Marshall et al., 2015).
Most researchers have studied the established paradigms (lean/ agile) and the green/sustainable paradigms as separate entities (e.g. Mollenkopf et al., 2010; Dües et al., 2013), while other researchers have begun discussing the implications of a potential compatibility between them, e.g. integrating lean and green practices or paradigms (Mollenkopf et al., 2010; Carvalho and Cruz-Machado, 2011; Martínez-Jurado and Moyano-Fuentes, 2014; Garza-Reyes, 2015; Wichaisri and Sopadang, 2017). However, despite some recent at-tempts, current studies neglect the social pillar of sustainability or omit agility-related aspects. The result is a lack of clarity as to how the environmental and social goals can be incorporated into established supply chains paradigms (Piercy and Rich, 2015).

Leveraging on this gap, this paper will address the following research question (RQ) through the use of a systematic literature review that focuses on lean, agile and sustainable supply chain paradigms: How do the established lean and agile supply chain paradigms integrate with the sustainable supply chain paradigm? We will answer to this question delineating some process steps to implement this integration and to point out uncovered areas and challenges for future researches.

It is worth highlighting here that the subject of sustainability is expansive and, while the importance of the economic pillar is recognised, research works about sustainable supply chain usually focus on the environmental and the social pillar only, so neglecting the economic pillar (Ashby et al., 2012). Similarly, hereinafter we will use the term "sustainability" to refer to "environmental and social sustainability".

The paper proceeds as follows. First, the research background and the methodology used for the systematic review are introduced. Secondly, we present a descriptive analysis of the sample of papers. Thirdly, we discuss and categorise the articles depending on the type of integration between the established and sustainable paradigms. The last two sections discuss the implications emerging from the categorisation, suggest a future research agenda and highlight the conclusions and the managerial implications.

\section{Background}

The need for, and opportunities to integrate various management paradigms were first highlighted by Naylor et al. (1999) in their seminal paper on 'Leagility: Integrating the lean and agile manufacturing paradigms in the total supply chain'. This work revealed that lean and agile manufacturing paradigms can be extended beyond the boundaries of a single company, thus defining the lean or agile supply chain paradigm, which includes, but it is not limited to, practices of lean or agile production paradigm. More recent studies indeed have also investigated the opportunities for integrating the lean and green paradigms (Mollenkopf et al., 2010; Martínez-Jurado and Moyano-Fuentes, 2014; Wichaisri and Sopadang, 2017). Looking at the relationship between lean and agile supply paradigms, Narasimhan et al. (2006) argue that established paradigms can be competing, precursor and complementary to each other. In terms of a competing relationship, for example, Dües et al. (2013) suggests that the differences between the Lean and Green paradigms lie in certain practices, such as the increase in replen-ishment frequency reducing inventory levels while increasing $\mathrm{CO}_{2}$ 
emissions connected to transportation. As for precursor, Mollenkopf et al. (2010) note that close collaboration with supply chain part-ners, which is an important practice for lean paradigm, is also a necessary condition for developing a green supply chain. For a complementary relationship, Kurdve et al. (2015) argue that the practice of waste flow mapping combines flow mapping, which is part of the lean paradigm, with waste associated with the environmental focus, which is part of the sustainable paradigm.

These examples suggest that the same established paradigm (i.e. lean or agile) can be at the same time competing, precursor and complimentary to the sustainable paradigm. Moreover, these contributions shed light on the fact that the integration between different paradigms lies in inter-dependencies in place between practices. This means that looking at the individual practices associated with each paradigm (e.g. high stock replenishment frequency, supplier collaboration, etc. for the lean paradigm) could help understanding the root cause of the different ways of integration. Therefore, our analysis of the literature will focus not only on the paradigms, but also, on the practices adopted under these paradigms. This in-depth analysis allows investigation of the reasons behind some possible contradictory results in the literature.

To satisfy the aim of our research, we have identified a set of practices for lean, agile and sustainable paradigm respectively. We acknowledge that there are papers that identify cross-paradigm approaches, thus suggesting hybrid practices, but we shall investigate them as one type of integration, with its associated practices, in the following parts of the paper.

In particular, practices associated with the agile supply chain paradigm can be classified in line with the definitions provided by Naylor et al. (1999) and Lee (2002) as follows:

- Risk hedging practices, such as: increased capacity surplus, supply chain risk management initiatives, risk hedging supply chain strategy;

- Flexibility and responsiveness practices, such as: flexible sourcing, flexible transportation, flexibility in product design (e.g. modularity), flexibility in production;

- Using supply chain knowledge for innovation, such as: customer involvement, mechanisms to promote innovation on the supply side, dynamic alliances and virtual network for product development.

As for lean practices, we acknowledge that literature is rich of notable contributions defining the pillars of lean production (e.g. Shah and Ward, 2007). Nevertheless, in line with our supply chainwide perspective, we adopted Naylor et al. (1999) and Lee (2002) as reference definitions for lean supply chain paradigm. We derived the following practices characterising a lean supply chain paradigm:

- Waste reduction practices such as: inventory, buffer capacity and materials reduction to produce exactly what needed (i.e. pull production) as well as reduction in defects and production process errors and wastes (through tools as: TQM, TPM, 5S, visual workplace, process mapping for certifications and value stream mapping);

- Closeness to suppliers' practices, namely focus on supply lead time reduction, geographical concentration of the supply base, close relationships with suppliers and direct deliveries from suppliers;

- Continuous improvement and workforce involvement practices as people-driven improvements in the production process through training, engagement and delegation;

- One piece flow, such as Just in Time (JIT) system, increase in replenishment frequency, set - up time reduction;
- Internal manufacturing efficiency practices as: investment in efficient production process technologies to increase in the utilisation rate and equipment efficiency.

Additionally, Lee (2002) highlights visibility as a fundamental practice of both lean and agile paradigms. To reach visibility, companies rely on information sharing with supply chain partners. In lean supply chains, the information sharing is meant to facilitate the implementation of cost optimisation. In agile supply chains, visibility helps in capturing customer requirements and timely communicating orders along the supply chain.

As far as the sustainable supply chain paradigm is concerned, many classifications of practices have been proposed, mainly taking an environmental focus (e.g. Rao and Holt, 2005; Vachon and Klassen, 2006). A few contributions, however, do encompass both environmental and social practices (e.g. Pagell and Wu, 2009; Parmigiani et al., 2011). We focus on environmental and social practices, leaving aside the economics sphere (e.g. collaborating with suppliers to improve operational performance) since these types of actions are part of the established supply chain paradigms. Given its exhaustiveness, we build on the classification of suppliers' related practices by Marshall et al. (2015) and Formentini and Taticchi (2016). We adopted the former to cover external sustainable supply chain practices (i.e. practices that rely on upstream relationships with suppliers). Formentini and Taticchi (2016) complement this list of practices by adopting an internal perspective, thus considering product and production process related aspects.

Therefore, we distinguish between:

- Environmental supply chain monitoring practices, such as monitoring suppliers' practices and policies;

- Environmental supply chain management systems, including the implementation of environmental management system to reduce pollution and wastes, ISO14000 certification, green purchasing;

- Environmental new product and process development, which includes the use of recycled materials and the design and production of products that can be re-used and recycled;

- Environmental supply chain strategy (re)definition, meaning for instance creating closed-loop supply chains and using waste as a resource;

- Social supply chain monitoring, such as implementing health and safety and well-being systems in the workplace and with suppliers;

- Social supply chain management systems, which includes, among the others, the definition of health and safety management procedures;

- Social new product and process development practices, which refer to the development of products and processes to ensure health and safety fair margins and wages and workers' welfare;

- Social supply chain strategy (re)definition practices, such as the inclusion of NGOs, community and charity groups in the decision making process.

Despite some of the more recent attempts to understand how various lean and agile practices might support or conflict with the adoption of the sustainability paradigm, no systematic understanding of the potential complementarity of the three paradigms and their underpinning practices exists. This is a first gap that our study aims to fill. Moreover, the systematic understanding we aim to develop includes also a discussion around possible contingencies in place, which might explain contradictions presented in the literature (i.e. contributions claiming synergies and contributions underlining a contrast between established and sustainable paradigms through considerations made on the same practice/set of practices). 


\section{Methodology}

A systematic literature review was conducted in our study, which relies on a rigorous and well-defined approach to reviewing the literature in a specific subject area (Vom Brocke et al., 2009). The recognised output of such literature review is to map, consolidate and evaluate the intellectual territory of a certain field as well as to identify knowledge gaps to be filled in order to develop the existing body of knowledge further (Tranfield et al., 2003). It can be performed adopting a meta-analysis or meta-synthesis method (Cronin et al., 2008). In managerial research, which deals with the understanding of organisations and management processes, researchers tend to use meta-synthesis, especially when dealing with qualitative studies (Tranfield et al., 2003).

The aim of the meta-synthesis we conducted was to summarise, integrate and cumulate the findings of different studies on the topic under investigation (Tranfield et al., 2003). Adopting a process model similar to Seuring and Müller (2008), as well as Gosling and Naim (2009) we organise the work along three steps:

- Material collection (section 3.1): setting the approach to select the papers by defining the exclusion and inclusion criteria, the sources to adopt as well as the unit of analysis (i.e. the paper).

- Descriptive analysis (section 3.2): providing temporal and journals distribution of the chosen papers as well as description of paper type (i.e. empirical: case studies based, survey based, simulation model based; theoretical: conceptual, literature review) and the analysed paradigms (i.e. lean, agile, lean and agile, environmental, social and sustainable).

- Thematic analysis (section 4): presenting the main finding of the literature review (categorisation and evaluation of the material to set future research paths).

\subsection{Material collection}

As hereinafter explained, two - steps approach (see Fig. 1) has been used to select the papers. In the first step the initial set of

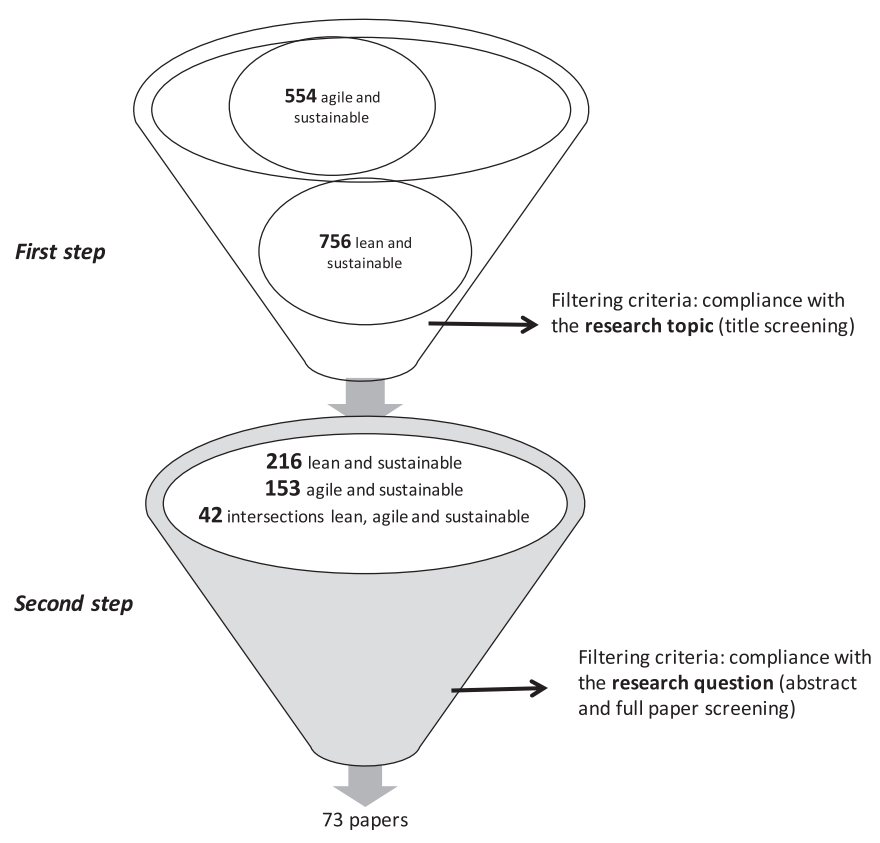

Fig. 1. Material collection. papers was collected based on a structured keyword search and the screening of the titles to retain papers that appear to be aligned with the general research topic (i.e. excluding contributions of different disciplines). During the second step the body of the text of each paper was analysed and the final list of papers was identified based on the adherence to the specific research question that we posed.

\subsection{First step: keyword extraction and title screening}

In the first step, the keywords derived from literature regard: leanness, agility, and sustainability. We included also two more keywords that the literature links with agile supply chain paradigm (Lee, 2002), namely "flexible" and "responsive". Moreover, in line with Tukamuhabwa et al. (2015), who claim that in the literature resilience is mostly connected with the concept of agility, we used also the keywords "resilient".

As for sustainability, the keywords were chosen in line with the TBL approach by Elkington (1997). However, in line with Ashby et al. (2012) and Gimenez and Tachizawa (2012) our focus is on the environmental and the social pillar only, so neglecting the economic pillar. Therefore "economic" was purposely not used, in order to not include those papers that limit the discussion to purely economic performance.

Thus, the keywords used were "lean", “agile", "responsive", "resilient", "flexible" in combination with "sustainability", "sustainable", "environmental", "green" and "social". These keywords are in line with the approach adopted by Seuring and Müller (2008) for their literature review on sustainable supply chain management. We searched these keywords in both abstract and title. For all the queries, "supply chain" was used as a further filter in the body of the text.

Scopus and Google Scholar databases were searched. Queries on the databases were performed in different time slots with the last update made in May 2017. Contributions ranging from the year 1999 to present were included in the research. The starting year is the publication year of Naylor et al. (1999) seminal paper addressing lean and agile as paradigms, as well as the idea of a possible integration between them. The research has been limited to journals, book chapters and, due to the novelty of the topic, conference proceedings.

As Fig. 1 outlines, 756 papers resulted from the query combining 'lean' and 'sustainable'-related keywords, whereas 554 resulted by the combination of 'agile' and 'sustainable' - related keywords. The title of each article has been screened to check the adherence of the paper to the general topic. For example, papers showing clearly a strong focus on information system design (e.g. agile programming, agile software development) or service management have been excluded, consistently with the definitions of lean and agile supply chain paradigms provided in the introduction, which clearly address manufacturing system. The output of the screening is a list of 411 papers: 216 papers dealing with lean and sustainable paradigms, and 153 with agile and sustainable paradigms. It is worth noticing that 42 papers are at the intersection, they indeed mention all three paradigms: lean, agile and sustainable (however, some papers just mention both lean and agile paradigms, but they revealed to have a marked focus on only one of them). Interestingly, after the screening of the titles, a high number of papers (540) dealing with lean paradigm were excluded because they tackle a wide range of aspects, without a clear focus on "lean" related aspects. On the contrary, we found that contributions related to the agile paradigm are based on a more recent concept and more likely to include a supply chain view. 


\subsection{Second step: analysis of the full body of the papers}

The second step encompasses the selection of the final list of papers for full text review based on the adherence to the research question, i.e. considering the integration between established supply chain paradigms and sustainable supply chain paradigm. To this purpose, abstracts and full body of the papers were reviewed (as in Gosling and Naim, 2009).

The output of the second step is a list of 73 papers that were selected for our final review. Table 1 lists the papers and classifies them based on the type of article: empirical works (i.e. case study, survey, mathematical quantitative methods and model application, action based research) or theoretical works (i.e. literature review and conceptual paper).

\subsection{Descriptive analysis}

The selected body of literature comprises papers that have been published in a 17-year period ranging from 2001 to 2017 (May). As Fig. 2 shows, most of the papers (90\%) have been published in the more recent years, starting from 2010, with the highest number of works (16) published in 2015, thus highlighting the growing interest devoted to the topic by scholars. Furthermore, the Journal of Cleaner Production dominates in terms of number of relevant studies, with 12 articles, followed by Benchmarking: an International Journal (5 papers), Supply Chain Management: an International Journal and In-ternational Journal of Production Research (4 papers each).

Table 2 captures the main focus of the 73 papers. The papers are classified based on the paradigms they concurrently refer to and

Table 1

Papers resulting from the two-step keyword search.

\begin{tabular}{|c|c|c|c|}
\hline Authors (year) & Journal/conference proceeding/book chapter title & ID & Article type \\
\hline Rothenberg et al. (2001) & Production and Operations Management & 1 & E: survey and in depth interviews \\
\hline King and Lenox (2001) & Production and Operations Management & 2 & E: survey based on secondary data \\
\hline Zhu and Sarkis (2004) & Journal of Operations Management & 3 & E: survey \\
\hline Kleindorfer et al. (2005) & Production and Operations Management & 4 & $\mathrm{~T}$ : literature review \\
\hline Simpson and Power (2005) Venkat & Supply Chain Management: an International Journal & 5 & E: exploratory case studies \\
\hline and Wakeland (2006) & $\begin{array}{l}\text { 50th Annual Meeting of the International Society for the } \\
\text { Systems Sciences 2006, ISSS } 2006\end{array}$ & 6 & E: simulation model \\
\hline Carvalho and Cruz-Machado (2011) & Supply Chain Management & 7 & T: conceptual \\
\hline Bae and Kim (2007) & IGLC Conference & 8 & E: case studies \\
\hline Kim et al. (2010) & Journal of Architectural Engineering & 9 & E: case studies \\
\hline Mollenkopf et al. (2010) & International Journal of Physical Distribution and Logistics Management & 10 & T: literature review \\
\hline Torielli et al. (2011) & 69th World Foundry Congress 2010, WFC 2010 & 11 & $\mathrm{~T}$ : literature review \\
\hline Parveen et al. (2011) & $\begin{array}{l}\text { Proceedings of the International Conference on Green Technology and } \\
\text { Environmental Conservation, GTEC-2011 }\end{array}$ & 12 & E: survey based on secondary data \\
\hline Vieira and Cachadinha (2011) & $\begin{array}{l}\text { 19th Annual Conference of the International Group for Lean } \\
\text { Construction 2011, IGLC } 2011\end{array}$ & 13 & E: single case study \\
\hline Vinodh et al. (2011) & Clean Technologies and Environmental Policy & 14 & E: case studies \\
\hline Yang et al. (2011) & International Journal of Production Economics & 15 & E: survey \\
\hline Azevedo et al. (2012) & IEEE Transactions on Engineering Management & 16 & E: single case study \\
\hline Cabral et al. (2012) & International Journal of Production Research & 17 & E: single case study \\
\hline Espadinha-Cruz et al. (2012) & $\begin{array}{l}\text { Proceedings of the International Conference on Information Technology } \\
\text { Interfaces, ITI }\end{array}$ & 18 & E: single case study \\
\hline Hong (2012) & Benchmarking: an International Journal & 19 & E: survey \\
\hline Puvanasvaran et al. (2012) & Journal of Industrial Engineering and Management & 20 & E: survey \\
\hline Rosenbaum et al. (2012) & IGLC 2012 - 20th Conference of the International Group for Lean Construction & 21 & E: single case study \\
\hline Youn et al. (2012) & Benchmarking: an International Journal & 22 & E: case studies \\
\hline Azevedo et al. (2013b) & $\begin{array}{l}\text { Airports and the Automotive Industry: Security Issues, Economic Efficiency and } \\
\text { Environmental Impact }\end{array}$ & 23 & E: single case study \\
\hline Duarte and Cruz-Machado (2013) & $\begin{array}{l}\text { Sixth International Conference on Management Science and Engineering } \\
\text { Management }\end{array}$ & 24 & E: single case study \\
\hline Dües et al. (2013) & Journal of Cleaner Production & 25 & $\mathrm{~T}$ : literature review \\
\hline Hajmohammad et al. (2013a) & Journal of Cleaner Production & 26 & E: survey \\
\hline Hajmohammad et al. (2013b) & Journal of Cleaner Production & 27 & E: survey \\
\hline Longoni et al. (2013) & International Journal of Production Research & 28 & E: case studies \\
\hline Maia et al. (2012) & International Journal of Industrial Engineering and Management & 29 & T: conceptual \\
\hline $\begin{array}{l}\text { Martínez-Jurado and } \\
\text { Moyano-Fuentes (2014) }\end{array}$ & Journal of Cleaner Production & 30 & T: literature review \\
\hline Silva et al. (2013) & IFAC Proceedings Volumes (IFAC-PapersOnline) & 31 & E: single case study \\
\hline Sobral et al. (2013) & Environmental Quality Management & 32 & E: single case study \\
\hline Wang et al. (2013) & $\begin{array}{l}\text { IEEE International Conference on Industrial Engineering and Engineering } \\
\text { Management }\end{array}$ & 33 & E: single case study \\
\hline Wiengarten et al. (2013) & Supply Chain Management: an International Journal & 34 & E: survey \\
\hline Azevedo et al. (2013a) & Journal of Cleaner Production & 35 & E: single case study \\
\hline Brown et al. (2014) & Journal of Cleaner Production & 36 & E: case studies \\
\hline Carvalho et al. (2017) & Lecture Notes in Electrical Engineering & 37 & E: single case study \\
\hline Govindan et al. (2014) & Journal of Cleaner Production & 38 & E: case studies \\
\hline Gunasekharan et al. (2014) Kurdve & Applied Mechanics and Materials & 39 & E: modelling \\
\hline et al. (2015) Puvanasvaran et al. & Journal of Cleaner Production & 40 & E: case studies \\
\hline (2014) Rosenbaum et al. (2014) & Journal of Industrial Engineering and Management & 41 & $\mathrm{~T}$ : conceptual \\
\hline Alves and Alves (2015) & Journal of Construction Engineering and Management & 42 & E: single case study \\
\hline Domingo and Aguado (2015) Dubey & International Journal of Production Research & 43 & $\mathrm{~T}$ : conceptual \\
\hline and Ali (2015) & Sustainability (Switzerland) & 44 & E: action based research \\
\hline Garza-Reyes (2015) & Benchmarking: an International Journal & 45 & E: survey \\
\hline \multirow[t]{2}{*}{ Govindan et al. (2015) } & Journal of Cleaner Production & 46 & $\mathrm{~T}$ : literature review \\
\hline & International Journal of Environmental Science and Technology & 47 & $\mathrm{~T}$ : conceptual \\
\hline
\end{tabular}


Table 1 (continued)

\begin{tabular}{|c|c|c|c|}
\hline Authors (year) & Journal/conference proceeding/book chapter title & ID & Article type \\
\hline Longoni and Cagliano (2015) & International Journal of Operations and Production Management & 48 & E: case studies \\
\hline Nieuwenhuis and Katsifou (2015) & Journal of Cleaner Production & 49 & E: single case study \\
\hline Piercy and Rich (2015) & International Journal of Operations and Production Management & 50 & E: case studies \\
\hline Rajesh and Ravi (2015) & Journal of Cleaner Production & 51 & E: single case study \\
\hline Schillig et al. (2015) & IFIP Advances in Information and Communication Technology & 52 & E: modelling \\
\hline Soni et al. (2015) & International Journal of Procurement Management & 53 & $\mathrm{~T}$ : conceptual \\
\hline Wu et al. (2015) & Sustainability (Switzerland) & 54 & E: case studies \\
\hline Yusup et al. (2015) & International Journal of Agile Systems and Management & 55 & $\mathrm{~T}$ : conceptual \\
\hline So and Sun (2015) & International Journal of Environmental Technology and Management & 56 & E: design of an experiment \\
\hline Fahimnia et al. (2015) & Omega (United Kingdom) & 57 & E: modelling \\
\hline Gorane and Kant (2017) & Benchmarking: an International Journal & 58 & E: survey \\
\hline Shibin et al. (2016) & Global Journal of Flexible Systems Management & 59 & E: experts' interviews \\
\hline Distelhorst et al. (2017) & Management Science & 60 & E: single case study \\
\hline Cherrafi et al. (2016) & International Journal of Production Research & 61 & E: case studies \\
\hline Garza-Reyes et al. (2016) & Production Planning and Control & 62 & E: case study and simulation \\
\hline Dev and Shankar (2016) & Benchmarking: an International Journal & 63 & E: modelling \\
\hline Ugarte et al. (2016) & Journal of Purchasing and Supply Management & 64 & E: discrete event simulation \\
\hline Campos and Vazquez-Brust (2016) & Supply Chain Management: an International Journal & 65 & E: single case study \\
\hline Kumar et al. (2016) & Competitiveness Review & 66 & $\mathrm{~T}$ :conceptual \\
\hline Wichaisri and Sopadang (2017) & Sustainable Development & 67 & $\mathrm{~T}$ :literature review \\
\hline Carvalho et al. (2017) & Resources, Conservation and Recycling & 68 & E: case study \\
\hline Duarte and Cruz-Machado (2017) & International Journal of Lean Six Sigma & 69 & E:case study \\
\hline Powell et al. (2017) & International Journal of Lean Six Sigma & 70 & E:case study \\
\hline Martínez and Javier (2017) & Journal of Cleaner Production & 71 & $\mathrm{~T}$ :literature review \\
\hline do Rosàrio Cabrita et al. (2016) & IFAC-PapersOnLine & 72 & T:conceptual \\
\hline Azevedo et al. (2016) & Benchmarking: an International Journal & 73 & E: case study \\
\hline
\end{tabular}

$\mathrm{E}=$ empirical work; $\mathrm{T}=$ theoretical work.

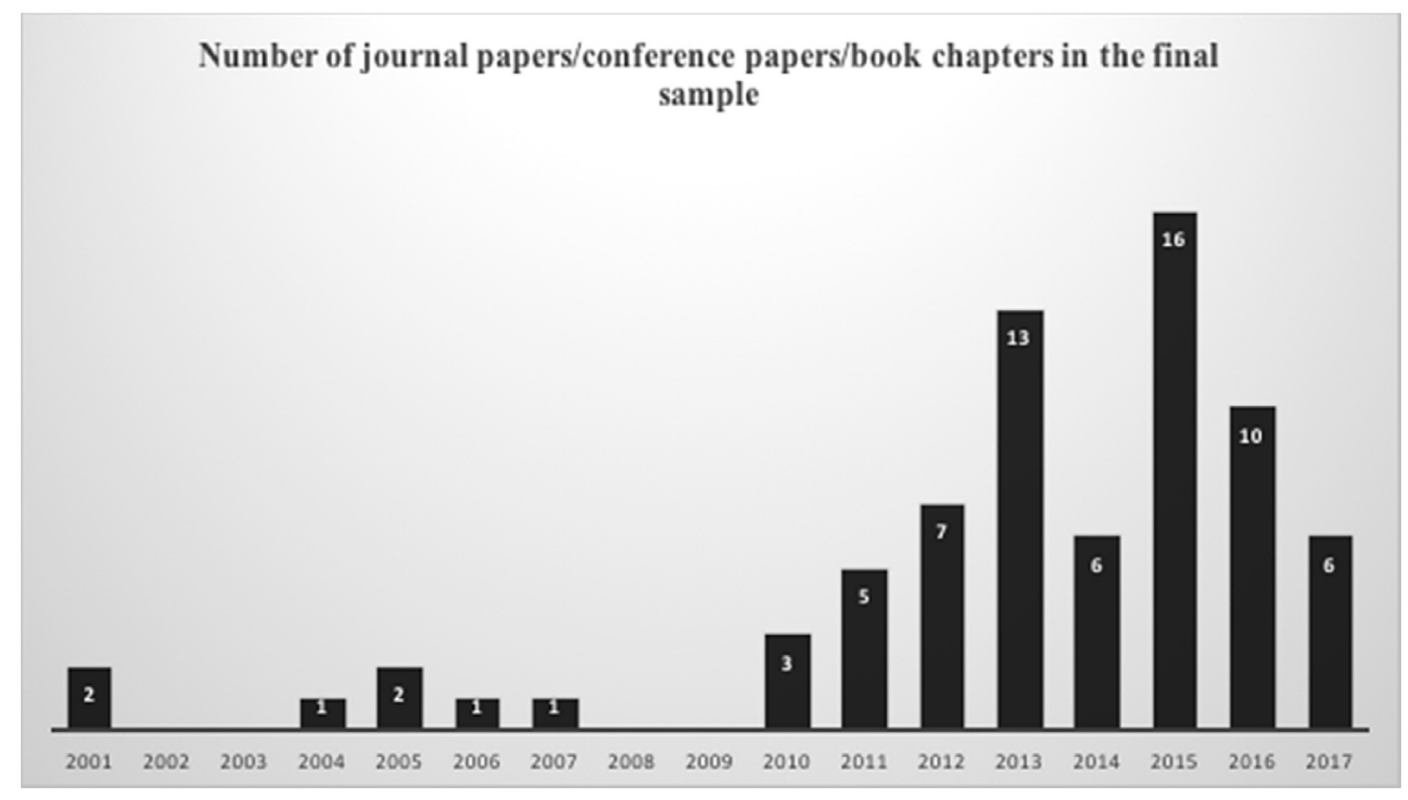

Fig. 2. Temporal distribution of papers in the final sample.

Table 2

Established supply chain paradigm and sustainability focus.

\begin{tabular}{|c|c|c|c|c|}
\hline & & Environmental & Social & $\begin{array}{l}\text { Environmental \& } \\
\text { social }\end{array}$ \\
\hline \multirow[t]{2}{*}{ Agile } & $\mathrm{E}$ & 59 & & 51 \\
\hline & $\mathrm{T}$ & & & 53 \\
\hline \multirow[t]{2}{*}{ Lean } & $\mathrm{E}$ & $\begin{array}{l}1 ; 2 ; 3 ; 5 ; 6 ; 8 ; 9 ; 12 ; 15 ; 16 \\
20 ; 21 ; 24 ; 26 ; 27 ; 31 ; 32 ; 34 \\
36 ; 39 ; 40 ; 42 ; 44 ; 45 ; 52 ; 57 \\
61 ; 62 ; 63 ; 65 ; 68 ; 69 ; 70\end{array}$ & $\begin{array}{l}28 ; 48 ; \\
60\end{array}$ & $\begin{array}{l}13 ; 14 ; 33 ; 50 ; 54 \\
56 ; 64\end{array}$ \\
\hline & $\mathrm{T}$ & $10 ; 11 ; 25 ; 29 ; 41 ; 46 ; 66$ & & $4 ; 30 ; 43 ; 55 ; 67$ \\
\hline Lean \& & $\mathrm{E}$ & $17 ; 18 ; 23 ; 35 ; 37 ; 38 ; 49 ; 58$ & & $19 ; 22$ \\
\hline agile & $\mathrm{T}$ & $7 ; 47$ & & \\
\hline
\end{tabular}

$\mathrm{E}=$ empirical studies; $\mathrm{T}=$ theoretical studies. based on the nature of the work (either empirical or theoretical). Most of the papers (40) study the lean supply chain paradigm integrated with the environmental dimension of the sustainable supply chain paradigm. Not surprisingly, not only is this focus the most covered in terms of number of contributions, but it appears also to be the most mature, given the higher numbers of empiricalbased papers rather than conceptual-based ones. Empirical articles focus on multiple or single in-depth case studies (e.g. Youn et al., 2012; Piercy and Rich, 2015), on surveys (e.g. Yang et al., 2011; Hajmohammad et al., 2013b) or model application (e.g. Shillig et al., 2015) Theoretical paper instead either develop a conceptual framework (e.g. Govindan et al., 2015; Yusup et al., 2015) or a 
literature review (e.g. Martínez-Jurado and Moyano-Fuentes, 2014; Garza-Reyes, 2015).

The focus on the social dimension is instead limited to just three empirical papers (i.e. Longoni et al., 2013; Longoni and Cagliano, 2015; Distelhorst et al., 2017).

The set of works taking both the social and the environmental perspective encompasses both empirical studies (e.g. Wang et al., 2013) and theoretical ones (e.g. Kleindorfer et al., 2005).

The agile supply chain paradigm results to be less studied than the lean paradigm and is the focus of only three papers: two empirical studies (Rajesh and Ravi, 2015; Shibin et al., 2016) and a conceptual paper (Soni et al., 2015). Two of them (Rajesh and Ravi, 2015; Soni et al., 2015) deal with the integration between agile, environmental and social paradigms.

Some contributions take a multi-paradigm perspective. Multiparadigm perspective devotes attention to both lean and agile and their integration with sustainability. In these works, integration targets either the environmental dimension only (e.g. Cabral et al., 2012; Espadinha-Cruz et al., 2012) or both the social and the environmental dimension (e.g. Carvalho and Cruz-Machado, 2011).

\section{Results}

\subsection{Integration categories}

Following the thematic content analysis of the 73 selected papers based on the ways the paradigms integrate, six categories have been found (see Table 3), namely:

1. Lean or Agile paradigms supporting sustainable paradigm: the implementation of lean or agile practices allows performance improvements to be achieved also within the area of sustainability, or lean or agile practices are considered as part of the sustainable paradigm. For instance, the concentration of the supply base in a geographical area is a lean practice (supply lead time is shorter) that contributes to the reduction of $\mathrm{CO}_{2}$ emissions (environmental performance) and positively impacts the

Table 3

Categories of lean \& sustainable and agile \& sustainable integration.

Category
1. Established paradigms
as supporting the
sustainable paradigm

${ }^{\mathrm{a}} \mathrm{n}=$ number of papers social dimension by creating jobs in the region (social performance).

2. Synergistic paradigms: synergies exist in the way some lean, agile, and sustainable practices affect supply chain performance. For instance, Carvalho and Cruz Machado (2017) observe that the three paradigms positively impact the service level performance because they increase the "integration level" between two supply chain entities. However, each paradigm affects the integration level through different practices. According to Carvalho and Cruz Machado (2017), the "integration level" is positively related to: the level of trust, openness and profit sharing of the traditional alliances in lean supply chains; the existence of dynamic alliances in the agile supply chains; the development of environmental risk sharing strategies and to the level of reverse material and information flow integration in the green supply chain. Therefore, Carvalho and Cruz-Machado (2011) conclude that the three paradigms independently (i.e. by means of different practices) synergistically affect the same supply chain attribute (e.g. integration level) and ultimately the same per-formance indicator (service level).

3. Established paradigms as complementary with sustainable paradigm: a lean/agile practice is modified to make it coherent with sustainable principles. For instance, the lean practice of workforce involvement can be extended to involve floor workers in monitoring chemicals usage (Rothenberg et al., 2001).

4. Lean and Agile paradigms as precursors of the sustainable paradigm. Similar as the concept of lean as antecedent of agile (Christopher and Towill, 2001) the implementation of lean or agile practices simplifies the implementation of sustainabilityrelated practices or boost the positive impact of sustainable practices on sustainable performance. For instance, Yang et al. (2011) state that the lean practice of process streamlining can help firms to adopt some environmental practices, such as an environmental management system.

5. Sustainable paradigm as precursor of lean/agile paradigms: the implementation of sustainability-related practices enables the implementation of lean or agile practices or boosts the positive impact of lean/agile practices on operational performance. For instance, environment protection system certifications are necessary practices to maintain competitiveness in an agile environment (Rajesh and Ravi, 2015).

6. Lean and agile paradigms as competing with the sustainable paradigm: the implementation of lean or agile practices negatively affects performance in the area of sustainability. For instance, Carvalho and Cruz-Machado (2011) claim that the agile practice of relying on capacity buffer to hedge against disruptions is detrimental to environmental performance, given the negative impact of this practice on resource consumption. The precursor, competing and complementary categories are to be interpreted in line with Narasimhan et al. (2006). In addition, we found that the lean and agile paradigms can be supportive of sustainable paradigm as well as the other way around. Interestingly, we found that paradigms can be synergistic too.

We carried out an in-depth analysis of the 73 articles in the sample and we classified them based on the integration category that they address. Each paper in the sample explores specific practices adopted as part of lean/agile or sustainable paradigm. Depending on the role of each practice, we conclude and classify the kind of integration claimed in the paper. Table 3 depicts the papers addressing each category of integration. It should be noted that the same paper can deal with several practices, resulting in various categories of integration.

With a closer look on the coverage in terms of number of papers in each integration category, we notice how established paradigms 
supporting sustainable paradigm is the mostly addressed form of integration $(n=37)$ both for lean $(n=35)$ and agile $(n=5)$, followed by precursor $(n=20)$ for lean and competing $(n=3)$ for agile. These differences in the coverage might reflect different fre-quency of occurrence of such integration due to the nature of the practices in each paradigm, or might simply reflect a different maturity in the literature on the established paradigms (the lean one appears to be way more developed than agile).

Most of the papers consider companies or supply chains that are already adopting established supply chain paradigms and that subsequently want to integrate the sustainable paradigm. Very few contributions are taking the point of view of a company that is already adopting the sustainable paradigm and wants to integrate established supply chain paradigms (i.e. sustainable precursor).

In the following sections, we present the classification of the papers dealing with: both agile and sustainable paradigm (section 4.2 ), both lean and sustainable paradigm (section 4.3), and synergistic paradigms (section 4.3 ).

In sections 4.2 and 4.3 , we describe the role of each practice in determining the integration between the paradigms.

For instance, paper 38 (Govindan et al., 2014) claims that the agile practice of risk hedging improves sustainability performance. Therefore, in section 4.2 we discuss the role of risk hedging as supporting the sustainable paradigm based on the evidence in paper 38. Moreover, in Table 4 we classify paper 38 in the first category of integration.

We carried out this analysis for every single practice cited in the papers of the sample. For the sake of readability, practices have been grouped into bundles of practices. For instance, flexibility in transportation and flexibility in product design have been grouped under "flexibility" (see section 4.2).

In sections 4.2 and 4.3 all the categories of integration are analysed, except the synergistic one. Papers dealing with the synergistic category highlight practices that are simultaneously relevant to all three paradigms, therefore they have been discussed in a dedicated section, i.e. section 4.4 .

The results are shown in Tables $3-5$, and discussed in the following sections.

In the following sections, we discuss for agile (section 4.2)and lean (section 4.3) supply chain paradigms how different categories of practices have been studied in terms of integration with the sustainable paradigm, providing some notable examples. We analysed the synergistic integration category in a separate section, building a discussion on both lean and agile or "hybrid" types of practices.

\subsection{Integrating the agile and sustainable supply chain paradigms}

Table 4 classifies the papers focusing on the integration between the agile paradigm and the sustainable paradigm. The table shows the group of practices (rows) that the authors of the papers claim to be relevant in determining each category of integration (column). For instance, Youn et al. (2012) (i.e. paper 22) find that flexibility is precursor to sustainability, therefore paper 22 is classified in the "Agility as precursors to sustainability" category of integration.

As far as the agile paradigm is concerned, most of the papers focus on the supporting integration category, while no contributions of the sample discuss complementary integration. Two sets of practices have been discussed in the literature as being both supporting and competing, namely risk hedging and flexibility.

As for risk hedging, Carvalho and Cruz-Machado (2011) claim that one major practice to guarantee hedging against disruptions is excessive buffer capacity, which is viewed as detrimental to environmental performance, given the negative impact of this practice on resource consumption. Govindan et al. (2014) also advocate that supply chain risk management practices could impact environmental performance, but they use or do not investigate further whether this impact is a positive or a negative one. Therefore, this fact led us to classify the type of integration as both supporting and competing.

Various practice associated with flexibility are discussed in the selected papers. Flexibility in transportation, for example, is perceived as a double-edged sword. On the one hand, it can be used to reduce environmental impact by choosing among different lot size deliveries (Fahimnia et al., 2015). On the other hand, it allows leveraging on motor-based urgent deliveries as part of contingency plans in case of a disruption (Govindan et al., 2014), thus increasing $\mathrm{CO}_{2}$ emissions. Flexibility in product design (i.e. the application of modular design) is also identified as enabling product remanufacturability, thus becoming a precursor of the sustainable paradigm (Youn et al., 2012). Finally, Shibin et al. (2016) claim that flexible manufacturing, through improved manufacturability of customised products (i.e. throughput time reduction and faster deliveries to end customers) enables green product design. Green product design, in turn, might mean to add a new "green" variant to a product family, thus increasing product variety and stimulating the adoption of flexible manufacturing.

One contribution (i.e. Youn et al., 2012) highlights the role of using supply chain knowledge for innovation, as a precursor of the sustainable paradigm. For instance, encouraging suppliers to propose innovations for the market can result in innovation also on the green front, thus producing a positive impact on the environmental dimension.

As for visibility, achieving end to end supply chain visibility reduces the need for material buffers, thus positively affecting environmental performance (Cabral et al., 2012).

As for sustainability practices, just environmental and social supply chain management systems out of the 8 categories of practices identified have been found in literature as precursors of

Table 4

Categories of practices (agile and sustainable) studied by papers in the sample depending on integration categories.

\begin{tabular}{|c|c|c|c|c|c|c|}
\hline \multirow[t]{2}{*}{ Categories of practices } & & \multicolumn{5}{|c|}{ Integration categories } \\
\hline & & Supporting & Complementary & $\begin{array}{l}\text { Agility as precursor } \\
\text { to sustainability }\end{array}$ & $\begin{array}{l}\text { Sustainability as } \\
\text { precursor to agility }\end{array}$ & Competing \\
\hline \multirow{4}{*}{ Agile practices } & Risk Hedging & 38 & & & & $7 ; 38$ \\
\hline & Flexibility & $7 ; 38 ; 57$ & & $22 ; 59$ & & $7 ; 37 ; 38$ \\
\hline & $\begin{array}{l}\text { Using supply chain knowledge } \\
\text { for innovation }\end{array}$ & 7 & & 22 & & \\
\hline & Visibility & 17 & & & & \\
\hline \multirow[t]{2}{*}{ Sustainability practices } & $\begin{array}{l}\text { Environmental supply chain management } \\
\text { systems }\end{array}$ & & & & $51 ; 59$ & \\
\hline & Social supply chain management systems & & & & 51 & \\
\hline
\end{tabular}


Table 5

Classification of papers according to categories of lean practices and integration category.

\begin{tabular}{|c|c|c|c|c|c|c|}
\hline \multicolumn{2}{|c|}{ Categories of practices } & \multicolumn{5}{|l|}{ Integration categories } \\
\hline & & Supporting & Complementary & $\begin{array}{l}\text { Leanness as } \\
\text { precursor } \\
\text { to sustainability }\end{array}$ & $\begin{array}{l}\text { Sustainability } \\
\text { as precursor } \\
\text { to } \\
\text { leanness }\end{array}$ & Competing \\
\hline \multirow[t]{6}{*}{ Lean practices } & $\begin{array}{l}\text { Continuous improvements and } \\
\text { workforce involvement }\end{array}$ & $\begin{array}{l}1 ; 12 ; 19 ; 31 ; 32 ; 33 ; 46 \\
48 ; 54 ; 69 ; 24 ; 65 ; 70 ; 60\end{array}$ & $1 ; 11 ; 48 ; 24$ & $\begin{array}{l}15 ; 25 ; 30 ; 48 ; 50 ; 56 ; 61 ; \\
65\end{array}$ & & \\
\hline & Waste reduction & $\begin{array}{l}2 ; 3 ; 7 ; 11 ; 12 ; 13 ; 17 ; 25 \\
30 ; 31 ; 38 ; 45 ; 46 ; 48 ; 54 \\
55 ; 61 ; 67 ; 69 ; 24 ; 65 ; 70 \\
71\end{array}$ & $\begin{array}{l}11 ; 14 ; 20 ; 36 ; 40 \\
41 ; 48 ; 52 ; 62\end{array}$ & $\begin{array}{l}2 ; 15 ; 22 ; 27 ; 45 ; 48 ; 50 \\
56 ; 61 ; 63 ; 66 ; 71\end{array}$ & & $1 ; 21 ; 42 ; 57$ \\
\hline & One piece flow & $\begin{array}{l}1 ; 3 ; 7 ; 8 ; 9 ; 12 ; 16 ; 29 ; 32 \\
38 ; 44 ; 45 ; 48 ; 54 ; 61\end{array}$ & $14 ; 48$ & $15 ; 26 ; 27 ; 28 ; 48$ & & $\begin{array}{l}6 ; 8 ; 25 ; 28 ; 30 ; 57 \\
61 ; 64 ; 68 ; 71\end{array}$ \\
\hline & Closeness to suppliers & $7 ; 16 ; 17 ; 25 ; 46 ; 68 ; 24 ; 71$ & $24 ; 65$ & $5 ; 10 ; 25 ; 27 ; 39 ; 50 ; 61 ; 65$ & & \\
\hline & Internal manufacturing efficiency & $7 ; 43 ; 24 ; 22$ & & & & \\
\hline & Visibility & $16 ; 64$ & & $10 ; 50$ & & 64 \\
\hline \multirow[t]{7}{*}{$\begin{array}{l}\text { Sustainability } \\
\text { practices }\end{array}$} & $\begin{array}{l}\text { Environmental new product and } \\
\text { process development }\end{array}$ & & & & 34 & \\
\hline & $\begin{array}{l}\text { Environmental supply chain } \\
\text { management systems }\end{array}$ & & & & $4 ; 34 ; 50$ & \\
\hline & $\begin{array}{l}\text { Environmental supply chain } \\
\text { monitoring }\end{array}$ & & & & 50 & \\
\hline & $\begin{array}{l}\text { Social supply chain management } \\
\text { systems }\end{array}$ & & & & $4 ; 50$ & \\
\hline & Social supply chain monitoring & & & & 50 & \\
\hline & $\begin{array}{l}\text { Social supply chain strategy } \\
\text { redefinition }\end{array}$ & & & & 50 & \\
\hline & Sustainability principles & & & & 43 & \\
\hline
\end{tabular}

agile practices. According to Rajesh and Ravi (2015) environmental and social supply chain management systems are considered prerequisites of other attributes for the selection of suppliers in the context of the agile supply chain paradigm. Environment protection system certifications (e.g. ISO 14001), as well as safety practices, are considered necessary practices to maintain competitiveness in a resilient (agile) environment.

\subsection{Integrating lean and sustainable supply chain paradigms}

Table 5 classifies those papers that focus on the integration between the lean and sustainable supply chain paradigms. The synergistic integration category, which highlights practices that are simultaneously relevant to all three paradigms, will be discussed in section 4.4 .

As shown in Table 5, several papers in the sample deal with practices playing a role in the supporting integration category, as well as in the precursor one. However, evidence has been found for each category of integration. This is different from the results about the integration between the agile paradigm and the sustainable paradigm (section 4.2), where the complementary category has no results.

In the following, for each group of practices we will discuss the role it plays when integrating the lean paradigm and the sustainable paradigm, based on the findings of the papers of the sample.

As far as the group continuous improvement and workforce involvement is concerned, Hong (2012) found that the group plays a supporting role. Through a survey of 379 companies, they validate the positive impact of several lean practices on sustainability. Among the others, they studied how micro and macro-organisational changes as well as the continuous improvement play a supporting role because they help the environmental performance improve. Wang et al. (2013) get to the same conclusions with regards to multifunctional employees and continuous improvement, by means of two case studies. They claim that continuous improvement and workforce involvement contribute to the increase of employees' wealth (social performance) and to waste reduction (environmental performance). The same practices are discussed years later by authors such as Duarte and Cruz-Machado (2017) as well as Distelhorst et al. (2017) as "lean and green" type of practices, thus emphasizing that a supporting integration exists among the two paradigms.

Some authors found that the group of practices plays the role of precursor. Yang et al. (2011) test and validate that the practices increasing the level of delegation and knowledge of workforce and implementation of a lean organisational model are precursors for the development of an environmental management system.

Rothenberg et al. (2001) notice how in lean plants the practice of workforce involvement could be extended to involve floor workers in areas such as the monitoring and reduction of chemicals usage, thus emphasizing that the practice has a role in the complimentary integration between the lean paradigm and the environmental paradigm.

Waste reduction is studied as having a supporting, complementary, precursor and even competing role in the context of sustainability by different authors.

As for the supporting category, according to Dües et al. (2013) the practices of waste reduction, which are typical of the lean paradigm, help to improve the environmental performance. The lean paradigm leverages on product and process changes to achieve a more efficient production process. These changes enable also product recycling (i.e. environmental supply chain management systems) as well as environmental new product and process development (i.e. design products to re-use its wastes) and supply chain strategy (re)definition (i.e. build a closed loop supply chain). Also Parveen et al. (2011) discuss the supporting role of six sigma. The authors claim that the practice can aid in detecting defects and eliminate waste with a direct positive impact on environmental performance. Similarly, Rothenberg et al. (2001) argue that the lower the buffer level, the more instantaneous the feedback about any problems during production is, making it easier to monitor waste and, hence, to reduce water and energy consumption.

Waste reduction practices play also a complementary role when integrating the lean and the sustainable paradigm. For instance, value stream mapping can be adapted to include sustainable 
elements. Brown et al. (2014) for example proposes to use sustainable value stream mapping as a monitoring tool that includes not only the monitoring on non-value added activities, but also environmental monitoring (i.e. energy and water usage) as well as social monitoring (i.e. risk faced by workers).

Under the precursor integration category falls a set of waste reduction practices such as 5 s cleanup and visual workplace that, according to Piercy and Rich (2015), are useful baselines to move from the lean paradigm applied in the workplace to the lean paradigm extended to the whole supply chain and ultimately to a sustainability strategy. When considering waste reduction intended as increasing quality conformance, King and Lenox (2001) state that companies adopting ISO 9000 quality standards are more likely to adopt ISO 14001 environmental standards, thus having a positive impact on environmental performance indicators.

Finally, waste reduction intended as increasing quality conformance can play a competing role, as Rothenberg et al. (2001) observe. The authors argue that in some processes (e.g. paint), the water use is critical to product quality. Superior quality pro-duction asks for high water usage, thus conflicting with the envi-ronmental goals.

Another group of practices whose integration with sustainability has been debated is one piece flow, which is considered as having a supporting, competing, precursor or complimentary role.

Procuring smaller and more frequent lots of parts from suppliers makes products spend less time in storage. Sobral et al. (2013) observe that, in the case study under their investigation, if the product spends less time in storage it is possible to avoid a washing operation on the product, so supporting sustainability goals.

The group of practices is considered as being competing with the sustainable supply chain paradigm when some contingencies are in place. According to Longoni et al. (2013) a manufacturing program having the primary goal to assure a continuous production (JIT) could harm the safety climate and negatively affect safety performance, if not accompanied with HR practices such as proper incentives, involvement, job rotation. Moreover, according to Dües et al. (2013), JIT deliveries in presence of a long and geographically dispersed supply chain is not to be considered "green", given that transportation is the major source of $\mathrm{CO}_{2}$ emissions (Dües et al., 2013).

As for the role of precursor, Hajmohammad et al. (2013a) discuss how JIT (as part of the lean management construct) can create an adequate operating context and a suitable route to facilitate the implementation of sustainable practices. Set up time reduction is analysed by Hajmohammad et al. (2013b) as part of a lean management construct that results to be precursor for the development of environmental practices such as pollution prevention and recycling of materials. The authors conclude that the implementation of these environmental practices is facilitated by the skills and the know-how gained when applying lean management principles, including, among others, set up time reduction. The same finding is confirmed by the simulation study by Ugarte et al. (2016), who, in the context of a two-echelon consumer good supply chain, demonstrate that JIT yields more than double carbon emissions than the baseline scenario (i.e. economic order quantity inventory management).

Lastly, Longoni and Cagliano (2015) advocate that JIT, under cross-functional executives' involvement, can be designed as aligned with operations' environmental and social sustainability goals. In the evidence they collected, JIT appears as complimentary with sustainability. They indeed analyze a case of a company that adopts a Takt Time based on workforce fatigue levels and breaks, thus combining health and safety principle with a JIT practice.

The literature discussing closeness to suppliers deals with supporting, precursor and complementary types of integration with sustainability. Azevedo et al. (2012) consider some practices that reduce supply lead time (i.e. deliveries directly to the point of use, geographical concentration of the supply base, lean supply network) as both lean and green practices. For example, geographical concentration of the supply base (i.e. the development of a suppliers' park) contribute to the reduction of $\mathrm{CO}_{2}$ emissions through the reduction of transportation routes, but it also positively impacts the social dimension by creating jobs in the region, producing a consequent positive effect in terms of welfare of local community.

When discussing close relationship with suppliers, Simpson and Power (2005) identify that the supplier-customer relationship is positively related to the implementation of environmental management practices of the supplying firm, thus delineating a precursor integration. With the same integration perspective, Gunasekharan et al. (2014) underline in a hierarchical conceptual model how supplier involvement is a precondition for disassembly intended as a waste reduction technique, given that suppliers should design parts to be easily dis-assembled or dismantled. Recently, Campos and Vazques Brust (2016) among lean and green supplier oriented practices, suggest that special types of awards for suppliers should be designed. These awards can bring "synergistic lean and green results" and include lean and environmental (i.e. waste, energy, emissions, water management) aspects. These considerations suggest that a to define the criteria upon which to establish these awards, complementary type of integration can be possible, adding green elements to lean oriented measures.

When it comes to internal manufacturing efficiency, the practices emerge to have a supporting integration role. Youn et al. (2012), for example, report that the implementation of a technological innovation in the production process of a steel manufacturer led the company initially to reap benefits in terms of lowered equipment and material costs, but secondly also in terms of air pollution. Moreover, the authors underline how this investment has led the company to bring into the market an environmentally friendly type of steel. Moreover, Alves and Alves (2015) argue that greater efficiency of production process not only would generate larger economic gain, but bring to consume less resources and production inputs as well as lower waste.

As for the visibility between supplier and manufacturer, Azevedo et al. (2012) claim that electronic data interchange (EDI) allows sharing higher quality information regarding production planning and scheduling, hence improving the accuracy of the information flow and consequently supporting an efficient and environmentally-friendly use of resources. In Mollenkopf et al. (2010) as well as in Piercy and Rich (2015), information sharing and transparency represent two precursors for the development of environmental management practices. According to Mollenkopf et al. (2010) information sharing represents a bridge between lean and green practices with the suppliers, whereas Piercy and Rich (2015) in their theoretical stage model for integrating lean and sustainable operations, point out how greater transparency between business partners is one of the starting point to develop a sustainability oriented strategy.

Finally, a set of practices of the sustainable supply chain paradigm has been identified as being precursor of the lean paradigm or as factors to increase the positive impact of sustainable practices on operational performance. For instance, according to Wiengarten et al. (2013), environmental supply chain management systems (i.e. compliance with ISO 14001 certification standard, pollution prevention) and environmental new product and process development (i.e. recycling of materials) are both factors that enhance the impact of lean practice on operational supply chain performance. Moreover, Piercy and Rich (2015) carry out some longitudinal case studies and observe that companies having a 
Table 6

Papers in the synergistic category and lean, agile, sustainable practices.

\begin{tabular}{|c|c|c|}
\hline \multicolumn{2}{|c|}{ Practices/attributes for the synergistic integration category } & \multirow{2}{*}{$\frac{\text { ID }}{23}$} \\
\hline \multirow[t]{16}{*}{ Practices } & $\begin{array}{l}\text { Adoption of fuzzy index for LARG supply chain decision } \\
\text { making }\end{array}$ & \\
\hline & $\begin{array}{l}\text { Adoption of Ecosilient index for LARG supply chain } \\
\text { decision-making }\end{array}$ & 35 \\
\hline & Adoption of LARG index for classifying LARG behaviours & 73 \\
\hline & Adoption of LARG key activities, resources, partners & 72 \\
\hline & Strategic stocks & 17 \\
\hline & $\begin{array}{l}\text { System for rapid response in case of emergencies and } \\
\text { special demands }\end{array}$ & \\
\hline & Reuse materials and packaging & \\
\hline & Supplier involvement & 18 \\
\hline & Use of compatible IT between actors & \\
\hline & $\begin{array}{l}\text { Use of IT to develop visibility on upstream and } \\
\text { downstream inventories }\end{array}$ & \\
\hline & Flexible transportation & \\
\hline & Flexible transportation & 47 \\
\hline & JIT with suppliers in the same industrial area & 47 \\
\hline & Responsive product strategy & 19 \\
\hline & Positioning of the decoupling point & 49 \\
\hline & $\begin{array}{l}\text { Operational responsiveness (lean manufacturing and } \\
\text { agile manufacturing) }\end{array}$ & 58 \\
\hline \multirow[t]{2}{*}{ Attributes } & Integration level & 7 \\
\hline & $\begin{array}{l}\text { Production and transportation lead time } \\
\text { Inventory level }\end{array}$ & \\
\hline
\end{tabular}

sustainability focus, rather than a lean orientation, already undertake a range of lean solutions for production problems, thus creating a "ready-made base for lean improvement".

\subsection{Synergistic paradigms}

In this category, the works address the topic of integrating both the lean and agile supply chain paradigms with the sustainable supply chain paradigm into a single integrated paradigm by means of a set of practices that contributes to create a lean - agile - sus-tainable paradigm. These contributions, although quite numerous in terms of number of papers, are limited to a few authors (i.e. Carvalho and Cruz-Machado, 2011; Azevedo et al., 2013a,b; Govindan et al., 2015). Starting from 2009, this group of authors has developed a research stream based on Lean, Agile, Resilient, and Green (LARG) paradigms, including supply chain practices and principles that synergistically affect traditional manufacturing and supply chain performance (i.e. inventory level, quality, customer satisfaction, time, cost) as well as environmental performance (e.g. business waste) and social (e.g. corruption risk) (Azevedo et al., 2012).

Table 6 shows the papers discussing more than one paradigm, identifying hybrid practices, capabilities, multi-paradigms performance indicators, thus creating a full joint paradigm perspective in which the practices and principles belonging to different strategies cannot be separated from each other. They study the integration between the established paradigms and the sustainable supply chain paradigms, as well as between the lean and agile supply chain paradigms.

Azevedo et al. (2013a,b) are classified into the synergistic paradigms category because they are centering their discussion around the formulation of fuzzy LARG index (Azevedo et al., 2013a) and ecosilient index (Azevedo et al., 2013b) to assess the joint LARG paradigm in an automotive supply chain. Additionally, part of the discussion carried out by Hong (2012) falls in this category too. They tested the mediating role of lean practices on the relationship between responsive product strategy (agility) and environmental performance (sustainability). Finally, Nieuwenhuis and Katsifou (2015) support this result and emphasise that the environmental and social performance is related to the positioning of the decoupling point in a leagile (leaned and agile) supply chain belonging to the automotive industry. Gorane and Kant (2017) add further elements to the discussion, claiming that green supply chain management and reverse logistics (i.e. sustainable practices) are precursor for the construct of "operational responsiveness", which includes lean manufacturing and agile manufacturing practices.

Carvalho and Cruz-Machado (2011) take a multi-paradigms perspective but discuss practices and principles of lean, agile and sustainable supply chain strategy separately. They claim that the three paradigms synergistically affect the following supply chain attributes: integration level, production and transportation lead time, and inventory level. For instance, they observe that the lean goal of inventory minimization (negatively) affects the inventory level; the agile practice of selecting suppliers that are flexible, pro-duce highquality products and deliver fast, affects inventory level too because the need of safety stocks is low; finally, the green practice of reducing redundant and unnecessary materials in the supply chain also helps to reduce inventory level. Therefore, the authors find that the three paradigms independently yet synergis-tically affect inventory level, as well as other supply chain attributes.

\section{Discussion and future research agenda}

From a theoretical perspective, the literature analysis shows a spectrum of diverse ways to integrate the established lean and agile supply chain paradigms with the sustainable paradigm. Findings suggest that lean-sustainable, agile-sustainable, or even lean-agilesustainable supply chain paradigms can be achieved by leveraging different integration categories. In the selected papers, the integration between lean and sustainable supply chain paradigms occur under the supporting, complementary, synergistic, precursor, and competing integration categories. The integration between agile and sustainable supply chain paradigms instead occurs under a smaller set of integration categories, namely supporting, precursor, and synergistic. This difference might be due to the different level of maturity of the literature on established paradigms: literature on lean supply chain paradigm is more developed than the one on agile supply chain paradigm.

The integration categories differ in terms of level of effort required for the integration of paradigms. In fact, both lean and agile supply chain paradigms can be integrated with sustainable paradigm by implementing already existing lean and agile practices (i.e. supporting category). Therefore, a company that is already developing a lean or agile supply chain paradigm might use practices that are already sustainable. This case requires a limited additional effort for the integration with sustainability. Higher integration effort is required when a lean supply chain paradigm is integrated with sustainability leveraging on a complementary or precursor integration. In fact, the company has either to adapt existing practices with sustainable principles (e.g. sustainable value stream mapping) or to implement new sustainable practices building upon existing lean or agile practices (i.e. precursor category). To integrate sustainability in the agile supply chain paradigm, new sustainable practices might have to be implemented, since we did not find evidence of contributions discussing the integration as complementary. Finally, when a company deals with practices that might be detrimental for the integration with the sustainable paradigm (i.e. competing paradigm) the effort should be directed towards avoiding the implementation of a certain practice or to contain its negative social and environmental impact.

The fact that the same lean or agile practice may act a role both as competing and as beneficial to sustainability goals (i.e. supporting, precursor, complementary, synergistic) in different papers might be contingent upon some contextual variables. For instance, 
this is the case of flexible transportation, which Carvalhoand Azavedo (2014) claim to be competing and Fahimnia et al. (2015) who claim it is supporting of the sustainable paradigm. Literature does not provide some tested contingencies in these regards, but does provide some studies that discuss how findings addressing the integration between established and sustainable supply chain paradigms refer to some specific industry (e.g. Hong, 2012; Distelhorst et al., 2017) or even to some specific operations, as transport (e.g. Garza-Reyes et al., 2016) or to a specific shop floor area (e.g. Rothenberg et al., 2001).

Beyond external context-related factors, the strategic role assigned to sustainability within corporate strategy might influence the amount of effort that the company is willing to allocate to the integration between the paradigms, and consequently the type of integration category. Indeed, literature has already claimed (e.g. Seuring and Müller, 2008; Wu and Pagell, 2011) that sustainability can be part of the corporate strategy or just seen as a constraint to be considered by supply chain managers. If sustainability is not strategically important, the company complies with minimum requirements for sustainability (e.g. regulations); to this purpose, the company might consider leveraging on practices already in use (i.e. supporting category). Whereas, if sustainability is the key to win competition, the company might invest in new practices (i.e. complementary and precursor categories). The former might be the case of companies that see sustainability as "nice to have" for their business, not worth ad-hoc investments, while in the latter sustainability assumes a higher strategic importance. Moreover, the integration category "sustainable precursor" can be of interest of those companies that perceive sustainability as a necessary condition to be eligible for competition, even when the orders are won based on established competitive priorities associated to the lean and agile paradigms. In fact, under the "sustainable precursor" category, sustainable practices can boost the positive impact of lean or agile practices on operational performance and this is extremely convenient for those type of companies. In this regard, it should be noticed that just two out of the eight categories of practices for the sustainable paradigm are analysed as precursor of the agile paradigm. These practices are environment protection systems and safety systems certifications. For the lean paradigm instead not just certifications, but also monitoring schemes, new product and process development, and supply chain strategy (re)definition are considered antecedents. This fact can shed a further light on a higher maturity for sustainability in lean contexts.

As for the integration category "synergistic", findings reveal that integration might be obtained leveraging on the synergies among different paradigms coexisting in a single supply chain. However, at the same time, trade-offs between the paradigms might occur, generating the need for making decisions on what set of practices to implement. Partially, contributions like Govindan et al. (2015) already addresses this issue by identifying practices that are considered "foundations" in a LARG (lean, agile, resilient and green) paradigm and upon which other LARG practices are built.

Thereby, we propose the following future research avenues:

- Conceptual and empirical studies on whether and how the choice of the integration category is contingent upon the strategic relevance of sustainability or other contingencies, e.g. the integration effort required to integrate sustainability with traditional supply chain paradigms;

- Conceptual and empirical studies of the role of sustainable practices as catalyst for the development of lean and agile practices;

- Conceptual and empirical studies analysing how to manage the integration of the three paradigms: lean, agile and sustainable and how to balance the trade-offs among them.
We believe that the study on the integration between established supply chain paradigms and sustainability should be approached with an evolutionary perspective to capture not only how but also why both lean and agile supply chains evolve to integrate sustainability. We acknowledge that Piercy and Rich (2015) suggest a "stage model" to integrate lean and sustainable operations. Despite the relevance of this contribution, the focus is limited to the lean paradigm and how integration with sustainability occurs, without discussing reasons and implication of such choice. Therefore, we recommend the following further research areas to be investigated in the near future:

- Empirical longitudinal studies of the evolutionary path of lean/ agile supply chains integrating sustainability.

- Empirical longitudinal studies on the evolution of supply chains of companies that have already integrated leanness with agility (i.e. leagile supply chain paradigm) and which aim to integrate also sustainability;

Finally, the results of this work show that there are understudied areas. The complex links between supply chain practices and environmental and social performance are still to be uncovered, and this is an interesting area for future research (Rothenberg et al., 2001). Understanding the trade-offs in place among the economic, social and environmental performance when implementing supply chain practices might be the basis for developing decision making models to choose the supply chain practice to implement when pursuing the sustainability goal, as well as to support policy makers in defining actions to support companies in their path towards sustainability. Moreover, researchers have focused on the integration between lean paradigm and environmental sustainability, partially neglecting the social one (as already stated by Martínez-Jurado and Moyano-Fuentes, 2014). Investigating the integration with social sustainability would help companies understanding how to address the complete set of sustainable performance. Furthermore, the integration between the agile supply chain paradigm and sustainability is also understudied, despite the relevance of agile supply chain paradigm for companies. From these considerations, the following research paths arise:

- Conceptual and empirical studies of the trade-offs between the social, environmental and economic performance when deciding which supply chain practice to implement;

- Inclusion of social aspects in conceptual and empirical studies on the integration between the established supply chain paradigms and sustainability;

- Empirical studies on agile supply chains integrating sustainability.

\section{Managerial implications}

From a managerial point of view, results support companies willing to integrate sustainability into their supply chains, as depicted in Fig. 3. Traditional models (Lee, 2002) support the definition of the established lean and agile supply chain paradigms. The integration category the company is to follow (see Table 3 ) is dependent upon the effort the company is ready to devote to integrate sustainability into already established supply chain management paradigms. The relevance of sustainability within the company's strategy represents the baseline for setting the level of effort required.

Fig. 3 shows a possible process to achieve integration between lean/agile and sustainable paradigms. In the first step, the strategic 


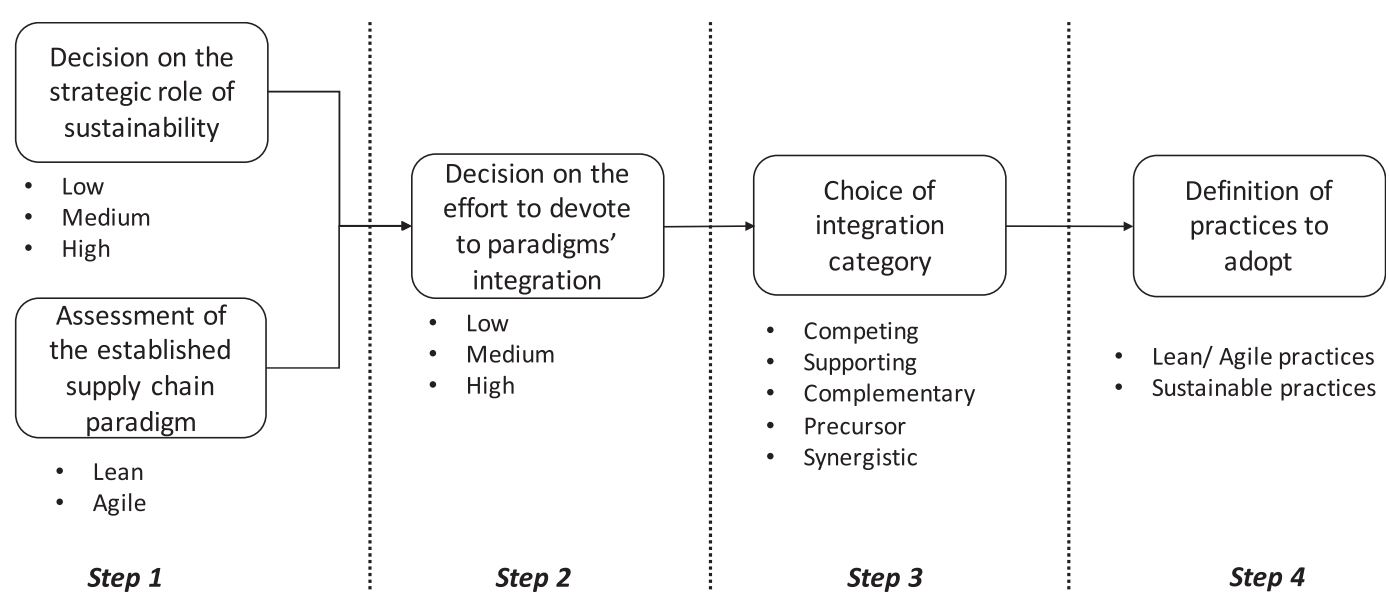

Fig. 3. Process for integrating lean/agile and sustainable paradigms.

importance of sustainability for a certain company is assessed and the positioning of the company with respect to practices is analysed.

The second step consists of deciding how much effort to devote to integrate or adapt existing practices to lead to environmental and social goals.

In the third step, the integration category is determined. In particular, five different ways of integrating traditional supply chain paradigm and sustainable one are possible. (i) Companies can leverage on already-in-use practices to increase the sustainable performance (i.e. the practices in the supporting category). (ii) They can integrate sustainable elements with already-in-use practices (i.e. complementary). (iii) They can leverage on traditional practices to set the basis for a future implementation of sustainable practices (i.e. precursor), and/or recognise the role of sustainability as a precursor for developing established practices (i.e. sustainability as precursor). (iv) Companies can reconsider the implementation of certain practices or opt for not implementing them at all (i.e. competing). Finally, (v) companies can decide to integrate the three paradigms together (i.e. synergistic).

Finally, in step 4, companies should define what practices to maintain or to adopt. Examples of these practices are shown in Tables 4-6.

Companies seeking to fit sustainability into an existing lean or agile supply chain strategy might, at first, enforce existing practices without any modifications or further investments (i.e. supporting integration), by applying what Piercy and Rich (2015) defined as "re-branding" initiatives. However, it should be noticed that rebranding specific isolated practices (i.e. not considering an integrated approach) can be a viable option for companies in which sustainability is less or not strategic. In line with Martínez and Javier (2017), this choice might be detrimental in the medium-long term. Moreover, companies should also be aware that prac-tices might be beneficial in terms of environmental impact, but not applicable in all contexts (e.g. opting for a geographically concentrated supply based in contexts in which global sourcing is strategic) (Carvalho et al., 2017).

As far as the agile paradigm is concerned, examples of "rebranded" practices are (see also Table 4): supplier selection based on flexibility, speed and quality, as well as dynamic alliances and virtual network (Carvalho and Cruz-Machado, 2011). Whereas, when it comes to the lean paradigm, reduction in the capacity surplus (Carvalho and Cruz-Machado, 2011), small batch size, kaizen and improvement teams (Hong, 2012) are examples of practices that can be rebranded and emphasised for sustainability purposes.
Moreover, when companies want to follow the way of embracing sustainability, they have to be sure they have laid the right foundations (leveraging on lean or agile practices as precursor for sustainable practices). These practices might be: information sharing (Martínez-Jurado and Moyano-Fuentes, 2014; Dües et al., 2013; Simpson and Power, 2005), JIT, manufacturing throughput time reduction, set-up time reduction, delegation and knowledge of the workforce, total quality management, maintenance programs for improving equipment productivity (Hajmohammad et al., 2013a), standardisation in the manufacturing process (Youn et al., 2012).

Furthermore, companies that opt for a complementary integration can adapt existing lean and agile practices and tools to include sustainable elements (Sobral et al., 2013).

Companies should also take into account that some practices have a controversial impact on sustainability performance. As show in Tables 4 and 5, a practice can belong both to competing and to any other integration categories. For instance, some authors attribute to JIT production and delivery a positive impact on sustainability performance (Govindan et al., 2014; Azevedo et al., 2012), while others advocate the negative impact due to more frequent not full truck load (FTL) transportations to the point of consumption (Martínez-Jurado and Moyano-Fuentes, 2014) or its detrimental impact on sustainability if not supported by other lean practices (Longoni et al., 2013). This implies the need for a company embracing the lean paradigm to reconsider the choice of heavily relying on JIT, considering what potential detrimental effect on environmental and social performance might arise and which contingencies to rely on to overcome these pitfalls.

Finally, some implications arise from the detection of synergies and trade-offs in place when implementing practices pertaining to more than two paradigms. For researchers, this can represent an important step in the direction of defining a new archetype of supply chain strategy that combines the characteristics of lean, agile and sustainable supply chains. We believe that this approach might be beneficial for managers whose companies pursue a hybrid strategy, e.g. leagile, which should understand how to implement lean and agile practices alongside sustainability, while minimising trade-offs.

\section{Conclusions}

With the present study, we aimed at shedding lights on how established lean and agile supply chain paradigms integrate with the sustainable supply chain paradigm. 73 contributions have been 
analysed and grouped based on the type of integration between established paradigms and sustainable paradigms. Three of the categories of integration (i.e. supporting, precursor, competing) are in line with the previous literature on established supply chain paradigms (Narasimhan et al., 2006). The supporting and the synergistic categories are original results of our work. The categorisation developed helps to clarify the logic behind existing constructs adopted so far in the literature to integrate leanness or agility with sustainability. We noticed how one paper should not, as a whole, be attributed to a single integration category, but distinctions are to be done analysing the single category of practices. The results of the literature review allow us to develop different paths for future researches addressing uncovered areas. They include the following studies on: how the choice of an integration category is contingent upon the strategic relevance of sustainability or other contingencies, the role of sustainable practices as catalyst for the development of lean and agile practices, how to manage the integration of the three paradigms: lean, agile and sustainable, the integration between agile supply chain paradigm and sustainability as well as the integration between established supply chain paradigms and the social dimension of sustainability, how and why lean and agile supply chain paradigms evolve integrating sustainability. Moreover, interesting managerial implications have been presented in the form of a process for defining the set of practices to implement when managers are integrating traditional and sustainable supply chain paradigms, depending on the traditional paradigm in use and the strategic role of sustainability.

Other disclosed areas for future researches relate to the limitations of the present study. The role played by integration effort in shaping the set of practices to implement is based on our discussion on literature review results, but it lacks of empirical evidence supporting it. This is out of the scope of a literature review, but it could be the starting point for further researches. Moreover, in this paper, we decided to provide a broad overview over groups of practices, e.g. one piece flow, without providing a detailed analysis of each specific practice, e.g. JIT, since the latter would have required more space than the one available in one paper. Future research can be devoted to analyze in details specific practices, to show the role they can play in supporting different integration strategies, with a specific focus on those practices that produce a contradictory impact on sustainability performance.

\section{References}

Ashby, A., Leat, M., Hudson-Smith, M., 2012. Making connections: a review of supply chain management and sustainability literature. Supply Chain Manag. Int. J. 17 (5), 497-516.

Alves, J.R.X., Alves, J.M., 2015. Production management model integrating the principles of lean manufacturing and sustainability supported by the cultural transformation of a company. Int. J. Prod. Res. 7543, 1-14.

Amnesty International, 2016. Indonesia: The Great Palm Oil Scandal: Labour

Abuses behind Big Brand Names: Executive Summary. URL. https://

www.amnesty.org/en/documents/asa21/5243/2016/en/.

Azevedo, S.G., Carvalho, H., Duarte, S., Cruz-Machado, V., 2012. Influence of green and lean upstream supply chain management practices on business sustain-ability. IEEE Trans. Eng. Manag. 59, 753-765.

Azevedo, S.G., Govindan, K., Carvalho, H., Cruz-Machado, V., 2013b. Ecosilient Index to assess the greenness and resilience of the upstream automotive supply chain. J. Clean. Prod. 56, 131-146.

Azevedo, S.G., Fazendeiro, P., Cruz-Machado, V., 2013a. A Fuzzy LARG Index Model to the Automotive Supply Chain. In Airports and the Automotive Industry: Security Issues, Economic Efficiency and Environmental Impact. Nova Publisher, pp. $125-144$.

Azevedo, S.G., Carvalho, H., Cruz-Machado, V., 2016. LARG index: a benchmarking

tool for improving the leanness, agility, resilience and greenness of the auto-motive supply chain. Benchmarking Int. J. 23 (6), 1472-1499.

Bae, J.W., Kim, Y.W., 2007. Sustainable value on construction project and application of lean construction methods. Proc. IGLC-15 16-22. BBC, 2013. Bangladesh textile Workers Deaths 'avoidable'. URL. http:// www.bbc.
Brown, A., Amundson, J., Badurdeen, F., 2014. Sustainable value stream mapping (Sus-VSM) in different manufacturing system configurations: application case studies. J. Clean. Prod. 85, 164-179.

Cabral, I., Grilo, A., Cruz-Machado, V., 2012. A decision-making model for Lean Agile, Resilient and Green supply chain management. Int. J. Prod. Res. 50, 4830-4845. Campos, L.M., Vazquez-Brust, D.A., 2016. Lean and green synergies in supply chain management. Supply Chain Manag. Int. J. 21 (5), 627-641. Carter, C.R., Rogers, D.S., 2008. A framework of sustainable supply chain management: moving toward new theory. Int. J. Phys. Distrib. Logist. Manag. 38 (5), 360-387. Carvalho, H., Azevedo, S., 2014. Trade-offs among lean, agile, resilient and green paradigms in supply chain management: a case study approach. In: Proceedings of the Seventh International Conference on Management Science and Engi-neering Management. Springer, Berlin, Heidelberg, pp. 953-968.

Carvalho, H., Cruz-Machado, V., 2011. Integrating lean, agile, resilience and green paradigms in supply chain management (LARG_SCM). Supply Chain Manag. In: Li, P. (Ed.), Supply Chain Management. InTech, Rijeka, Croatia, pp. 27-48. Available from: http://www.intechopen.com/books/supply-

chainmanagement/integrating-lean-agile-resilience-and-green-paradigms-insupply-chain-management-larg-scm-.

Carvalho, H., Govindan, K., Azevedo, S.G., Cruz-Machado, V., 2017. Modelling green and lean supply chains: an eco-efficiency perspective. Res. Conserv. Recycl. 120, 75-87. Cherrafi, A., Elfezazi, S., Govindan, K., Garza-Reyes, J.A., Benhida, K., Mokhlis, A., 2016. A framework for the integration of Green and Lean Six Sigma for superior sustainability performance. Int. J. Prod. Res. 55 (15), 4481-4515.

Christopher, M., Towill, D.R., 2002. Developing market specific supply chain strategies. Int. J. Log. Manag. 13 (1), 1-14.

Christopher, M., Towill, D., 2001. An integrated model for the design of agile supply chains. Int. J. Phys. Distrib. Logist. Manag. 31 (4), 235-246.

Cronin, P., Ryan, F., Coughlan, M., 2008. Undertaking a literature review: a step-bystep approach. Br. J. Nurs. 17 (1), 38-43.

Dev, N.K., Shankar, R., 2016. Using interpretive structure modeling to analyze the interactions between environmental sustainability boundary enablers. Bench. Int. J. 23 (3), 601-617.

Distelhorst, G., Hainmueller, J., Locke, R.M., 2017. Does lean improve labor standards? Management and social performance in the Nike supply chain. Manag. Sci. 63 (3), 707-728.

do Rosário Cabrita, M., Duarte, S., Carvalho, H., Cruz-Machado, V., 2016. Integration of lean, agile, resilient and green paradigms in a business model perspective: theoretical foundations. IFAC-PapersOnLine 49 (12), 1306-1311.

Domingo, R., Aguado, S., 2015. Overall environmental equipment effectiveness as a metric of a lean and green manufacturing system. Sustainability 7 (7), 9031-9047.

Duarte, S., Cruz-Machado, V., 2013. Lean and green supply chain initiatives: a case study. In: IIE Annual Conference. Proceedings. Institute of Industrial EngineersPublisher.

Duarte, S., Cruz Machado, V., 2017. Green and lean implementation: an assessment in the automotive industry. Int. J. Lean Six Sigma 8 (1), 65-88.

Dubey, R., Ali, S.S., 2015. Exploring antecedents of extended supply chain performance measures: an insight from Indian green manufacturing practices.

Benchmarking Int. J. 22 (5), 752-772.

Dües, C.M., Tan, K.H., Lim, M., 2013. Green as the new Lean: how to use Lean practices as a catalyst to greening your supply chain. J. Clean. Prod. 40, 93-100.

Elkington, J., 1997. Cannibals with Forks: The Triple Bottom Line of 21st Century Business. Capstone, Oxford.

Espadinha-Cruz, P., Cabral, I., Grilo, A., Cruz-Machado, V., 2012. Information model for LARGeSCM interoperable practices. In: Information Technology Interfaces (ITI), Proceedings of the ITI 2012 34th Int. Conf. on Information Technology Interfaces, Croatia.

Fahimnia, B., Sarkis, J., Eshragh, A., 2015. A tradeoff model for green supply chain planning: a leanness-versus-greenness analysis. Omega (United Kingdom) 54 $173-190$.

Formentini, M., Taticchi, P., 2016. Corporate sustainability approaches and goverance mechanisms in sustainable supply chain management. J. Clean. Prod. 112, 1920-1933.

Garza-Reyes, J.A., 2015. Lean and Green - a systematic review of the state of the art literature. J. Clean. Prod. 102, 18-29.

Garza-Reyes, J.A., Villarreal, B., Kumar, V., Molina Ruiz, P., 2016. Lean and green

in the transport and logistics sector-a case study of simultaneous deployment. Prod. Plan. Contr. 27 (15), 1221-1232.

Gimenez, C., Tachizawa, E.M., 2012. Extending sustainability to suppliers: a systematic literature review. Supply Chain Manag. Int. J. 17 (5), 531-543.

Gorane, S., Kant, R., 2017. Supply chain practices and organizational performance-an empirical investigation of Indian manufacturing organizations. Int. J. Log. Manag. 28 (1)

Gosling, J., Naim, M.M., 2009. Engineer-to-order supply chain management: a literature review and research agenda. Intern. J. Prod. Econ. 122, 741-754.

Govindan, K., Azevedo, S.G., Carvalho, H., Cruz-Machado, V., 2014. Impact of supply chain management practices on sustainability. J. Clean. Prod. 85, 212-225.

Govindan, K., Azevedo, S.G., Carvalho, H., Cruz-Machado, V., 2015. Lean, green and resilient practices influence on supply chain performance: interpretive structural modeling approach. Int. J. Environ. Sci. Technol. 12 (1), 15-34. Greenpeace,

2007. Palm oil: Cooking the Climate. Once You Pop, You Can't Stop. URL. http://www.greenpeace.org/international/en/news/features/palm-oil_ cooking-the-climate. 
Gunasekharan, S., Elangovan, D., Parthiban, P., 2014. Critical success factors for implementation of lean and green in medium scale manufacturing industries. Appl. Mech. Mater. 592-594, 2588-2595.

Hajmohammad, S., Vachon, S., Klassen, R.D., Gavronski, I., 2013a. Lean management and supply management: their role in green practices and performance. J. Clean. Prod. 39, 312-320.

Hajmohammad, S., Vachon, S., Klassen, R.D., Gavronski, I., 2013b. Reprint of Lean management and supply management: their role in green practices and per-formance. J. Clean. Prod. 56, 86-93.

Heydari, J., 2011. Paradigms of supply chain management. In: Farahani,

R., Rezapour, S., Kardar, L. (Eds.), Supply Chain Sustainability and Raw Material Management: Concepts and Processes. IGI Global, Hershey, PA, pp. 149-175.

Hong, P., Jungbae Roh, J., Rawski, G., 2012. Benchmarking sustainability practices: evidence from manufacturing firms. Benchmarking Int. J. 19 (4/5), 634-648. Kim, Y., Asce, A.M., Bae, J., 2010. Assessing the environmental impacts of a lean supply System: case study of high-rise condominium construction in Korea. ACSE Libr. 16, 144-150.

King, A.A., Lenox, M.J., 2001. Lean and green? An empirical examination of the relationship between lean production and environmental performance. Prod. Oper. Manag. 10, 244-256.

Kleindorfer, P.R., Singhal, K., Wassenhove, L.N., 2005. Sustainable operations management. Prod. Oper. Manag. 14, 482-492.

Kumar, B.R., Agarwal, A., Sharma, M.K., Sharma, M.K., 2016. Lean management-a step towards sustainable green supply chain. Compet. Rev. 26 (3), 311-331.

Kurdve, M., Shahbazi, S., Wendin, M., Bengtsson, C., Wiktorsson, M., 2015. Waste flow mapping to improve sustainability of waste management: a case study

approach. J. Clean. Prod. 98, 304-315.

Lee, H.L., 2002. Aligning supply chain strategies with product uncertainties. Calif. Manag. Rev. 44, 105-119.

Longoni, A., Pagell, M., Johnston, D., Veltri, A., 2013. When does lean hurt? - an exploration of lean practices and worker health and safety outcomes. Int. J.

Prod. Res. 51, 3300-3320.

Longoni, A., Cagliano, R., 2015. Cross-functional executive involvement and worker involvement in lean manufacturing and sustainability alignment. Int. J. Oper. Prod. Manag. 35, 1332-1358.

Maia, L.C., Alves, A.C., Leão, C.P., July 2012. Sustainable work environment with lean production in textile and garment industry. In: Proceedings of International Conference on Industrial Engineering and Operations Management (ICIEOM2012), pp. 9-11.

Marshall, D., McCarthy, L., Heavey, C., McGrath, P., 2015. Environmental and social supply chain management sustainability practices: construct development and measurement. Prod. Plan. Cont. 26, 673-690. Martínez-Jurado, P.J., Moyano-Fuentes, J., 2014. Lean management, supply chain management and sustainability: a literature review. J. Clean. Prod. 85, 134-150. Martínez, L.H.C., Javier, C.A., 2017. Towards lean for sustainability: Understanding the interrelationships between lean and sustainability from a systems thinking perspective. J. Clean. Prod. 142 (4), 4384-4402.

Mollenkopf, D., Stolze, H., Tate, W.L., Ueltschy, M., 2010. Green, lean, and global supply chains. Int. J. Phys. Distrib. Logist. Manag. 40, 14-41.

Narasimhan, R., Swink, M., Kim, S.W., 2006. Disentangling leanness and agility: an empirical investigation. J. Oper Manag. 24, 440-457.

Naylor, J.B., Naim, M.M., Berry, D., 1999. Leagility: integrating the lean and agile manufacturing paradigms in the total supply chain. Int. J. Prod. Eco. 62 (1), 107-118.

Nieuwenhuis, P., Katsifou, E., 2015. More sustainable automotive production through understanding decoupling points in leagile manufacturing. J. Clean. Prod. 95, 232-241.

Pagell, M., Wu, Z.H., 2009. Building a more complete theory of sustainable supply chain management using case studies of 10 exemplars. J. Supply Chain Manag. 45, 37-56.

Parveen, C.M., Kumar, A.R.P., Narasimha Rao, T.V.V.L., 2011. Integration of lean

andgreen supply chain - impact on manufacturing firms in improving environmental efficiencies. In: Proc. Int. Conf. Green Technol. Environ. Conserv. GTEC-2011, pp. 143-147.

Powell, D., Lundeby, S., Lundeby, S., Chabada, L., Chabada, L., et al., 2017. Lean

Six Sigma and environmental sustainability: the case of a Norwegian dairy pro-

ducer. Int. J. Lean Six Sigma 8 (1), 53-64.

Piercy, N., Rich, N., 2015. The relationship between lean operations and sustainable operations. Int. J. Oper. Prod. Manag. 35, 282-315.

Puvanasvaran, P., Swee, R.K., Suresh, V., Muhamad, M., 2012. Lean principles adoption in environmental management system (EMS)-ISO 14001. J. Ind. Eng. Manag. 5 (2), 406

Puvanasvaran, P., Tian, R.K.S., Vasu, S.A.L., 2014. Lean environmental management integration system for sustainability of ISO 14001:2004 standard imple-mentation. J. Ind. Eng. Manag. 7, 1124-1144.

Rajesh, R., Ravi, V., 2015. Supplier selection in resilient supply chains: a grey rela tional analysis approach. J. Clean. Prod. 86, 343-359.

Rao, P., Holt, D., 2005. Do green supply chains lead to competitiveness and economic performance? Int. J. Oper. Prod. Manag. 25, 898-916.

Rosenbaum, S., Toledo, M., Gonzalez, V., 2012. Green-lean approach for assessing environmental and production waste in construction. In: Proceedings IGLC-20. Toledo.
Rosenbaum, S., Toledo, M., González, V., 2014. Improving environmental and production performance in construction projects using value-stream mapping: case study. J. Constr. Eng. Manag. 140, 1-11.

Rothenberg, S., Pil, F.K., Maxwell, J., 2001. Lean, green, and the quest for superior environmental performance. Prod. Oper. Manag. 10, 228-243.

Schillig, R., Stock, T., Egon, M., 2015. Energy value-stream mapping a method to visualize waste of time and energy. In: IFIP International Conference on Advances in Production Management Systems. Springer International Publishing, pp. 609-616.

Seuring, S., Müller, M., 2008. From a literature review to a conceptual framework for sustainable supply chain management. J. Clean. Prod. 16, 1699-1710. Shah, R., Ward, P.T., 2007. Defining and developing measures of lean production. J. Oper. Manag. 25 (4), 785-805.

Shibin, K.T., Gunasekaran, A., Papadopoulos, T., Dubey, R., Singh, M., Wamba,

S.F., 2016. Enablers and barriers of flexible green supply chain management: a total interpretive structural modeling approach. Gl. J. Flex. Syst. Manag. 17 (2), 171-188.

Silva, C., Vaz, P., Ferreira, L.M., 2013. The impact of Lean Manufacturing on environmental and social sustainability: a study using a concept mapping approach.

IFAC Proc. 46, 306-310.

Simpson, D.F., Power, D.J., 2005. Use the supply relationship to develop lean and green suppliers. Supply Chain Manag. Int. J. 10 (1), 60-68.

So, S., Sun, H., 2015. Lean thinking as organisational practice in enabling supply chain sustainability. Int. J. Env. Tech. Manag. 18, 291-308.

Sobral, M.C., Sousa Jabbour, A.B.L.D., Chiappetta Jabbour, C.J., 2013. Green benefits from adopting lean manufacturing: a case study from the automotive sector.

Env. Qual. Manag. 22 (3), 65-72.

Soni, U., Jain, V., Salmador, M.P., 2015. Coping with uncertainties via resilient supply chain framework. Int. J. Proc. Manag. 8 (1-2), 182-201.

Torielli, R.M., Abrahams, R.A., Smillie, R.W., Voigt, R.C., 2011. Using lean

methodologies for economically and environmentally sustainable foundries.

China Foundry 8, 74-88.

Tranfield, D., Denyer, D., Smart, P., 2003. Towards a methodology for developing evidence-informed management knowledge by means of systematic review. Br. J. Manag. 14, 207-222.

Tukamuhabwa, B.R., Stevenson, M., Busby, J., Zorzini, M., 2015. Supply chain resilience: definition, review and theoretical foundations for further study. Int. J.

Prod. Res. 53 (18), 5592-5623.

Ugarte, G.M., Golden, J.S., Dooley, K.J., 2016. Lean versus green: the impact of lean logistics on greenhouse gas emissions in consumer goods supply chains. J. Purch. Supply Manag. 22 (2), 98-109.

Vachon, S., Klassen, R.D., 2006. Extending green practices across the supply chain: the impact of upstream and downstream integration. Int. J. Oper. Prod. Manag.

26, 795-821.

Venkat, K., Wakeland, W., 2006. Is lean necessarily green?. In: Proceedings of the 50th Annual Meeting of the ISSS-2006, Sonoma, CA, USA.

Vieira, A.R., Cachadinha, N., 2011. Lean construction and sustainability - complementary paradigms? a case study. In: Proceeding 19th Annu. Conf. IGLC, pp. 611-621.

Vinodh, S., Arvind, K.R., Somanaathan, M., 2011. Tools and techniques for enabling sustainability through lean initiatives. Clean. Technol. Environ. Policy 13 , 469-479. Vom Brocke, J., Simons, A., Niehaves, B., Riemer, K., Plattfaut, R., Cleven, A., June 2009. Reconstructing the giant: on the importance of rigour in documenting the literature search process. In: ECIS, vol. 9, pp. 2206-2217.

Vonderembse, M.A., Uppal, M., Huang, S.H., Dismukes, J.P., 2006. Designing supply chains: towards theory development. Int. J. Prod. Eco. 100, 223-238.

Wichaisri, S., Sopadang, A., 2017. Trends and future directions in sustainable development. Sust. Dev. (in press).

Wang, Z., Subramanian, N., Abdulrahman, M., Liu, C., 2013. Composite practices to improve sustainability: a framework and evidence from Chinese auto-parts company. IEEE Int. Conf. Ind. Eng. Eng. Manag. 1047-1051.

Wiengarten, F., Fynes, B., Onofrei, G., 2013. Exploring synergetic effects between investments in environmental and quality/lean practices in supply chains. Supply Chain Manag. Int. J. 18 (2), 148-160.

Wu, L., Subramanian, N., Abdulrahman, M.D., Liu, C., Lai, K.H., Pawar, K.S., 2015. The impact of integrated practices of lean, green, and social management systems on firm sustainability performance-evidence from Chinese fashion auto-parts suppliers. Sustain 7, 3838-3858.

Wu, Z., Pagell, M., 2011. Balancing priorities: decision-making in sustainable supply chain management. J. Oper. Manag. 29, 577-590.

Yang, M.G., Hong, P., Modi, S.B., 2011. Impact of lean manufacturing and environmental management on business performance: an empirical study of manufacturing firms. Int. J. Prod. Econ. 129, 251-261.

Youn, S., Yang, M.G (Mark), Roh, J.J., 2012. Extending the efficient and responsive supply chains framework to the green context. Benchmarking Int. J. 19, 463-480.

Yusup, M.Z., Mahmood, W.H.W., Salleh, M.R., Yusof, A.S.M., 2015. Review the influence of lean tools and its performance against the index of manufacturing

sustainability. Int. J. Agile Sys. Manag. 8 (2), 116-131.

Zhu, Q., Sarkis, J., 2004. Relationships between operational practices and performance among early adopters of green supply chain management practices in Chinese manufacturing enterprises. J. Oper. Manag. 22, 265-289. 